
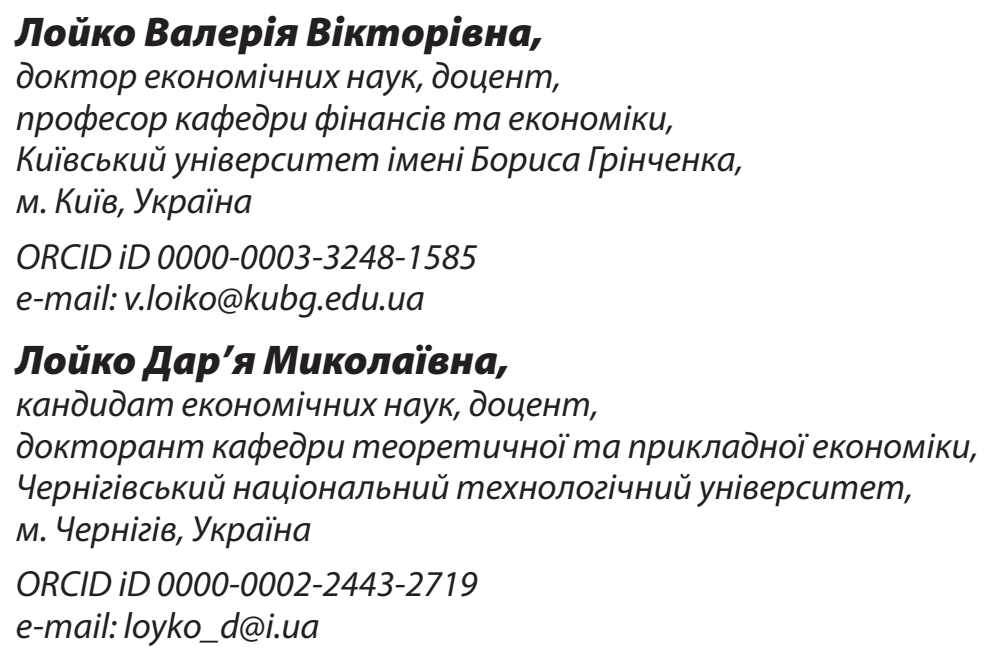

\title{
ЗАБЕЗПЕЧЕННЯ ЯКОСТІ ФОРМУВАННЯ ФАХОВИХ КОМПЕТЕНЦІЙ ЕКОНОМІСТІВ У СУЧАСНОМУ УКРАÏНСЬКОМУ УНІВЕРСИТЕТІ В УМОВАХ ЄВРОІНТЕГРАЦІї
}

\begin{abstract}
Анотація. Дана стаття є результатом наукового дослідження щодо виявлення напрямів підвищення якості формування фахових компетенцій економістів у сучасному українському університеті в умовах євроінтеграчії. За сучасним українським законодавством якість освіти формується зовнішньої системою, яку підтримує МОНУ та НАЗЯВО і внутрішньою системою, яку кожний заклад вищої освіти формує самостійно. Євроінтеграційне спрямування розвитку економіки України потребує більшої автономії університетів для більш швидкого реагування на запити фрахівців для ринку праці. Зовнішнє оцінювання якості освіти у вигляді щорічних рейтингів закладів вищої освіти впливає на вибір абітурієнтів та часто їх батьків щодо обрання закладу для навчання. Абітурієнти при обранні закладу вищої освіти для подальшого навчання часто користуються інформачією, отриманою у соиіальних мережах. Формуючи внутрішню систему якості освіти закладу вищої освіти потрібно подбати про правдиву інформацію про університет в різних джерелах інформаиії. Сформована матриия SWOT-аналізу системи формування фахових компетентностей бакалаврів та магістрів з економіки дозволила виявити сильні сторони, недоліки, можливості та загрози сучасної системи якості в українських закладах вищої освіти. Виділено підсистеми зовнішнього та внутрішнього рівнів системи забезпечення якості освіти. Внутрішня система якості освіти складається із наступних підсистем: моніторингу відповідності фахової підготовки викладачів вимогам МОНУ; моніторингу якості викладання навчальних дисциплін; моніторингу набутих компетентностей студентами; моніторингу відповідності фрахових компетентентностей, які закладено до освітньо-професійних та освітньо-наукових програм, реаліям ринку прачі; стратегічного планування розвитку системи якості освіти університету. Для підсистем внутрішнього рівня системи забезпечення якості освіти підібрано відповідні сучасні інструменти, які дають можливість здійснювати якісний вимір. Перспективними напрямами підвищення рівня якості освіти в українських університетах єпрактико орієнтоване навчання студентів, зв'язок із роботодавиями та узгодження змісту освітньо-професійних програм із фахівиями-практиками, здійснення наукових досліджень студентами під час навчання в університеті.
\end{abstract}

Ключові слова: Україна; система освіти; якість; SWOT-аналіз; компетентності; наукові дослідження; підготовка економістів; євроінтеграція. 


\section{ВСТУП}

Постановка проблеми. Підвищення рівня якості освіти $€$ одним із ключових чинників підвищення конкурентоздатності країни. За сучасним українським законодавством якість освіти регулюється зовнішньою системою, яка сформована Міністерством освіти та науки України (МОНУ) та Національним агентством із забезпечення якості вищої освіти (НАЗЯВО) і внутрішніми системи закладів вищої освіти, які можуть відрізнятися. Євроінтеграційний напрям розвитку економіки України потребує більшої автономії університетів для більш гнучкого реагування на потреби ринку праці. Щорічний перегляд освітніх та освітньо-наукових програм підготовки фахівців надає можливість вчасно вносити корективи у навчальні плани та підвищувати рівень якості освіти з метою більшої відповідності підготовлених фахівців вимогам ринкового середовища. Набуття міжнародного досвіду у підготовці фахівців допомагає сформувати компетентності майбутніх фахівців таким чином, щоб вони були конкурентоздатними на міжнародному ринку праці. Зважаючи на сучасні процеси глобалізації світової економіки та євроінтеграційні процеси української економіки система оцінки якості освіти при формуванні фахових компетенцій економістів потребує удосконалення та подальшого розвитку. Покращення якості освіти фахівців, зокрема економістів, в умовах євроінтеграційних процесів та програм міжнародної мобільності сприятиме зростанню конкурентоздатності майбутніх спеціалістів та підвищенню рейтингу університету.

Аналіз останніх досліджень і публікацій. Питанням розробки методичних і практичних аспектів забезпечення якості освіти у сучасних українських університетах займаються такі вчені: С. Архіпова, О. Александрова, Н. Віннікова, Т. Лукіна, О. Ляшенко, О. Локшина, В. Сафонова, Н. Задорожнюк, Т. Хлебнікова, та інші. Зважаючи на велику кількість праць, в яких розглянуто різні аспекти освітнього процесу, та враховуючи сучасні зміни при реформуванні системи забезпечення якості у закладах вищої освіти та реформування економіки країни, доцільно провести дослідження щодо ефективних напрямів забезпечення якості формування фахових компетентностей економістів у сучасному університеті.

Мета статті полягає у дослідженні стану системи якості освіти сучасного українського університету та обгрунтуванні напрямів підвищення якості формування фахових компетенцій економістів у сучасному українському університеті в умовах євроінтеграції.

\section{РЕЗУЛЬТАТИ ДОСЛІДЖЕННЯ}

Однією із умов конкурентоздатності закладу вищої освіти $\epsilon$ наявність у нього внутрішньої системи якості освіти, яка відповідає сучасним вимогам національних та міжнародних стандартів. Процес створення таких систем у закладах вищої освіти відбувається повільно, що може привести до певних втрат у формуванні інтелектуального потенціалу країни. Такі втрати можуть у подальшому позначатися і рівні національної безпеки. Фахівці з економіки працюють в усіх сферах національної економіки та на всіх видах підприємств. Реформування економіки, яке триває всі роки незалежності України, вимагає від фахівців грунтовного рівня знань. Вимоги сучасного ринку праці, який за умови євроінтеграції розширюється до країн Європейського Союзу, потребує від фахівця не тільки знань та навичок в межах спеціальності, а й сформованих особистісних та професійних компетентностей, знання іноземної мови, здатності до самоосвіти, вміння працювати в команді та продукувати нові ідеї, соціального рівня відповідальності за прийняті професійні рішення. Такі вимоги ринку праці у свою чергу потребують відповідних змін у навчальному процесі закладів вищої освіти, зокрема контролю за якістю освіти. Формування фахових компетенцій у економістів та надання сучасного рівня знань має велике значення для подальшого розвитку економіки країни в умовах глобалізаційних викликів та євроінтеграційного розвитку економіки України. Тому формування внутрішньої системи оцінки якості формування фахових компетенцій майбутніх фахівців всіх спеціальностей i, зокрема, економістів, є важливим для забезпечення сталого розвитку економіки країни та вирішення питань економічної безпеки.

Процес оцінювання якості освіти у закладах вищої освіти триває протягом існування системи вищої освіти. Змінюються методи та інструменти оцінювання якості освіти. Змінюється саме поняття якості вищої освіти. Обираючи місце майбутнього навчання абітурієнти та їх батьки користуються інформацією зовнішньої системи оцінки якості освіти, це, зазвичай, рейтинги університетів. Проте не тільки рейтинг університету впливає на вибір абітурієнтів. Часто батьки рекомендують своїм дітям той університет, в якому вони самі отримали освіту. Абітурієнти прислуховуються і до думки старших друзів, які навчаються в тому чи іншому університеті. На вибір навчального закладу впливає і інформація, яку абітурієнти отримують у соціальних 
мережах. Тому, будуючи внутрішню систему якості освіти, доцільно подбати про якісну та правдиву інформацію про університет у різних інформаційних мережах.

SWOT-матриця дозволяє виділити сильні та слабкі сторони, а також можливості і загрози сучасної системи формування фахових компетенцій економістів в українських закладах вищої освіти (табл. 1).

Система забезпечення якості освіти має два рівні оцінювання: зовнішній та внутрішній $[1,2,3]$.

Таблиия 1

\section{ПЕРЕВАГИ ТА НЕДОЛІКИ, МОЖЛИВОСТІ ТА ЗАГРОЗИ СУЧАСНОЇ СИСТЕМИ ФОРМУВАННЯ ФАХОВИХ КОМПЕТЕНЦІЙ БАКАЛАВРІВ ТА МАГІСТРІВ З ЕКОНОМІКИ В УКРАЇНСЬКИХ ЗАКЛАДАХ ВИЩОЇ ОСВІТИ.}

\begin{tabular}{|c|c|}
\hline Strengths (сильні сторони) & Weaknesses (недоліки) \\
\hline $\begin{array}{l}\text { - достатній та високий рівень викладання фахових } \\
\text { дисципліни, що надає можливість отримати сту- } \\
\text { дентам достатній теоретичний рівень підготовки } \\
\text { для формування фахових компетенцій; } \\
\text { - зацікавленість всіх учасників освітнього процесу } \\
\text { у достовірній інформації та об'єктивних результа- } \\
\text { тах процесу формування фахових компетентностей } \\
\text { економістів. }\end{array}$ & $\begin{array}{l}\text { - недосконалі бази для проходження виробничої } \\
\text { практики (часто процес проходження виробничої } \\
\text { практики відбувається формально, що не надає мож- } \\
\text { ливості отримати студентам необхідного рівня прак- } \\
\text { тичних навичок для майбутньої роботи); } \\
\text { - нестабільність сучасного ринку праці, що не на- } \\
\text { дає впевненості майбутнім фахівцям у забезпече- } \\
\text { ності їх місцем роботи за фахом і отриманим рівнем } \\
\text { кваліфікації. }\end{array}$ \\
\hline Opportunities (можливості) & Threats (загрози) \\
\hline $\begin{array}{l}\text { - можливості дистанційного навчання та отри- } \\
\text { мання додаткових знань з фахових дисциплін; } \\
\text { - отримання досвіду навчання в зарубіжних } \\
\text { університетах за рахунок роботи програм з міжна- } \\
\text { родного обміну та удосконалення фахових компе- } \\
\text { тенцій із урахуванням міжнародного досвіду; } \\
\text { - можливості суміщення практичної роботи та на- } \\
\text { вчання у магістратурі за рахунок гнучкості графіків } \\
\text { навчального процесу. }\end{array}$ & $\begin{array}{l}\text { - брак досвіду українських університетів у забезпе- } \\
\text { чення власної автономії; } \\
\text { - обмежені можливості стажування викладачів для } \\
\text { набуття навичок викладання фахових дисциплін } \\
\text { за світовими стандартами; } \\
\text { - перманентні зміни законодавчо-правових актів, що } \\
\text { регулюють діяльність закладів вищої освіти; } \\
\text { - недостатній рівень оплати праці висококваліфіко- } \\
\text { ваних викладачів фахових дисциплін, що викликає } \\
\text { відтік цих фахівців в інші галузі. }\end{array}$ \\
\hline
\end{tabular}

Джерело: складено авторами за власними спостереженнями та узагальненням досвіду роботи

До складових зовнішньої системи оцінювання якості формування компетентностей майбутніх фахівців в українській системі вищої освіти можна віднести наступні:

1) формування стандартів освіти;

2) процедури ліцензування та акредитації освітньої діяльності;

3) державна атестація;

4) рейтингове оцінювання.

До складових внутрішньої системи оцінювання якості формування фахових компетентностей майбутніх фахівців та, зокрема, економістів відносяться наступні:

1) підсистема моніторингу відповідності фахової підготовки викладачів вимогам МОНУ;

2) підсистема моніторингу якості викладання навчальних дисциплін;

3) підсистема моніторингу набутих компетентностей студентами;
4) підсистема моніторингу відповідності фахових компетентентностей, які закладено до освітньо-професійних та освітньо-наукових програм, реаліям ринку праці.;

5) підсистема стратегічного планування розвитку системи якості освіти університету.

Для виділених підсистем внутрішньої системи оцінювання якості формування фахових компетентностей майбутніх фахівців підібрано інструменти, які допомагають здійснити якісну оцінку (табл. 2).

До позитивної практики університетів у забезпеченні моніторингу якості формування фахових компетенцій варто віднести рецензування освітніх та освітньо-наукових програм підготовки фахівців зовнішніми рецензентами, як фахівцями інших закладів вищої освіти так і практиками. 


\section{ІНСТРУМЕНТИ ВНУТРІШНЬОЇ СИСТЕМИ ОЦІНЮВАННЯ ЯКОСТІ ФОРМУВАННЯ ФАХОВИХ КОМПЕТЕНТНОСТЕЙ МАЙБУТНІХ ФАХІВЦІВ}

\begin{tabular}{|l|l|}
\hline \multicolumn{1}{|c|}{ Підсистема } & \multicolumn{1}{|c|}{ Інструменти } \\
\hline $\begin{array}{l}\text { Підсистема моніторингу відповідності фахової підго- } \\
\text { товки викладачів вимогам МОНУ. }\end{array}$ & $\begin{array}{l}\text { Кадрові вимоги щодо забезпечення провадження } \\
\text { освітної діяльності у сфері вищої та післядиплом- } \\
\text { ної освіти для осіб з вищою освітою }\end{array}$ \\
\hline $\begin{array}{l}\text { Підсистема моніторингу якості викладання навчаль- } \\
\text { них дисциплін. }\end{array}$ & $\begin{array}{l}\text { Оцінка змісту робочих навчальних програм (часто } \\
\text { проводиться формально); перевірка наявності ме- } \\
\text { тодичного забезпечення навчальної дисципліни, }\end{array}$ \\
\hline $\begin{array}{l}\text { Підсистема моніторингу набутих компетентностей } \\
\text { студентами. }\end{array}$ & $\begin{array}{l}\text { Поточні контролі знань за різними формами про- } \\
\text { ведення; підсумковий контроль знань }\end{array}$ \\
\hline $\begin{array}{l}\text { Підсистема моніторингу відповідності фахових компе- } \\
\text { тентентностей, які закладено до освітнь-професійних } \\
\text { та освітньо-наукових програм, реаліям ринку праці. }\end{array}$ & $\begin{array}{l}\text { Зворотній зв'язок з роботодавцями щодо якості } \\
\text { Оцінювання звітів з практики. }\end{array}$ \\
\hline $\begin{array}{l}\text { Підсистема стратегічного планування розвитку систе- } \\
\text { ми якості освіти університету. }\end{array}$ & $\begin{array}{l}\text { Відкриття нових освітньо-професійних та освіт- } \\
\text { ньо-наукових програм та закриття неконкуренто- } \\
\text { здатних освітніх програм. } \\
\text { Розробка та своєчасне ії удосконалення системи } \\
\text { оцінки якості освітніх програм та їх відповідності } \\
\text { запитам ринку праці. }\end{array}$ \\
\hline
\end{tabular}

\section{Джерело: складено авторами за власними спостереженнями та узагальненням досвіду роботи}

Якість рівня підготовки сучасного фахівця залежить не тільки від суми теоретичних знань та набуття практичних навичок в період навчання, а й від можливості займатися інтелектуальною працею, а саме приймати участь у наукових заходах та публікувати наукові праці. Розвиток наукової складової є дуже важливим для підготовки майбутнього фахівця. За рахунок наукової складової в освіті економістів закладається здатність мислити інноваційно, шукати науково обгрунтовані рішення з економічних питань. Потрібно зауважити, що наукова активність студентів не є стабільною величиною із року у рік. Аналіз кількості опублікованих наукових праць студентів у збірниках матеріалів щорічних науково-практичних конференцій за практичним досвідом кафедри фінансів та економіки Київського університету імені Бориса Грінченка показав наступну динаміку: 2013 р. - 120 тез доповідей; 2014 р. - 95 тез доповідей; 2015 р. 37 тез доповідей; 2016 р. - 41 тези доповідей; 2017 р. - 69 тез доповідей; 2018 р. - 44 тези доповідей. Нестабільність динаміки публікацій результатів студентських наукових досліджень свідчить про те, що потрібно активніше залучати студентів до наукової роботи, мотивувати студентів займатися науковими дослідженнями, публікувати результати цих досліджень не тільки в українських наукових виданнях а й у міжнародних. Активне залучення студентів до наукових досліджень надасть можливість сфор- мувати у студента систему інноваційного мислення, що є дуже важливою вимогою сучасного ринку праці.

Якість освіти у закладах вищої освіти оцінюється за певними стандартами. Виділяють 12 систем оцінки стандартів якості освіти. До міжнародних стандартів оцінки якості освіти віднесено наступні системи: ISO 9001:2015, ASIN, ABET, THE-ICE. До національних стандартів віднесено наступні: MBNQA, CAQC, AAQ, NIAD-UE, JUAA, JIHEE, TEQSA, CAA [4]. Національні системи застосовують у різних країнах. Міжнародні системи можуть бути застосовано в усіх країнах. В Україні застосовують стандарт ISO 9001:2015 [5]. Цим стандартом передбачено наступні критерії досягнення якісних переваг: орієнтація на клієнта, лідерство, залучення людей, технологічний (процесний) підхід, удосконалення, прийняття рішень на основі фактичних даних, управління взаємодіями.

Переваги здійснення внутрішнього аудиту системи якості освіти очевидні. Ці переваги обумовлені триєдиним зв'язком між адміністрацією закладу вищої освіти, студентами, та роботодавцями. Існує зацікавленість керівництва університетів у отриманні об'єктивних даних щодо процесу підготовки майбутніх фахівців; зацікавленість студентів у отриманні сучасного рівня освіти; зацікавленість роботодавців у достатньому та високому рівні підготовленості майбутніх робітників для виконання своїх робочих 
обов’язків. Роботодавці не зацікавлені у вкладанні додаткових коштів у додаткову підготовку молодих працівників. Тому більш жорсткі умови ринку праці вимагають від майбутніх фахівців отримання більше практичних навичок при проходженні навчання у вищому навчальному закладі. Особливість підготовки фахівців з економіки обумовлена тим, що ці фахівці можуть працювати на підприємствах різної форми власності, в організаціях. Іноземних фірмах, банках, страхових та інвестиційних компаніях, відділах місцевих державних адміністрацій та інших організаціях, що вимагає від них певних знань та навичок. Безумовно, що навчальні плани підготовки бакалаврів та магістрів за спеціальністю економіка не можуть передбачити всього, проте склад навчальних дисциплін дозволяє студентам сформувати основу економічних знань. Iз переліку економічних спеціальностей спеціальність 051 Економіка має найбільш широкий спектр працевлаштування випускників, що вимагає від розробників освітньо-професійних програм та навчальних планів грунтовних знань щодо підготовки майбутніх економістів.

\section{ВИСНОВКИ ТА ПЕРСПЕКТИВИ ПОДАЛЬШИХ ДОСЛІДЖЕНЬ}

Результати проведеного дослідження дають можливість зробити наголос на те, що провідна роль у формуванні якісної системи освіти в українських закладах вищої освіти в умовах євроінтеграції належить людським чинникам, a саме: укомплектованості складу науково-педагогічних працівників, його відповідності вимогам МОНУ, достатньому рівню вмотивованості праці всіх співробітників університету, проведення наявність підрозділу якості освіти в університеті, який забезпечує проведення внутрішнього контролю системи якості освіти. Перспективними напрямами підвищення рівня якості освіти є практико орієнтоване навчання студентів, зв'язок із роботодавцями та здійснення наукових досліджень студентами під час навчання в університеті.

Перспективи подальших досліджень полягають у виявленні чинників, які впливають на зовнішню та внутрішню системи якості освіти та оцінка їх впливу, розробка кількісних показників оцінки якості освіти.

\title{
СПИСОК ВИКОРИСТАНИХ ДЖЕРЕЛ
}

1. Про вищу освіту: Закон України № 1556-VII в редакцій від 01.01.2019. [Електронний ресурс]. - Режим доступу: https://zakon.rada.gov.ua/laws/show/1556-18.

2. Про освіту: Закон України № 2145-VIII від 05.09.2017. [Електронний ресурс]. - Режим доступу: http://search.ligazakon.ua/l_doc2.nsf/link1/T172145.html.

3. Про національну стратегію розвитку освіти в Україні на період до 2021 року: Указ Президента України № 344/2013 від 25.06.2013 р. [Електронний ресурс]. - Режим доступу: https:// zakon3.rada.gov.ua/laws/show/344/2013.

4. Aleksandrova O., Batchenko L., Dielini M., Lavryk U. Specifics of Managing Competitiveness of Present-day University on Principles of Social Responsibility. (2018) Naukovyi Visnyk Nacionalnogo Hirnychogo Universitetu (Scientific Bulletin of National Mining University). No 4. pp. 15-165.

5. ДСТУ ISO 9001:2015. Системи управління якістю. [Електронний ресурс]. - Режим доступу: http://khoda.gov.ua/image/catalog/files/\%209001.pdf

\section{ОБЕСПЕЧЕНИЕ КАЧЕСТВА ФОРМИРОВАНИЯ ПРОФЕССИОНАЛЬНЫХ КОМПЕТЕНЦИЙ ЭКОНОМИСТОВ В СОВРЕМЕННОМ УКРАИНСКОМ УНИВЕРСИТЕТЕ В УСЛОВИЯХ ЕВРОИНТЕГРАЦИИ}

\author{
Лойко Валерия Викторовна, \\ доктор экономических наук, дочент, \\ профессор кафедры финансов и экономики, \\ Киевский университет имени Бориса Гринченко, \\ 2. Киев, Украина \\ ORCID iD 0000-0003-3248-1585 \\ e-mail:v.loiko@kubg.edu.ua
}

\author{
Лойко Дарья Николаевна, \\ кандидат экономических наук, доцент, \\ докторант кафедры теоретической и прикладной экономики, \\ Черниговский национальный технологический университет, \\ 2. Чернигов, Украина \\ ORCID iD 0000-0002-2443-2719 \\ e-mail: loyko_d@i.ua
}


Аннотация. Данная статья является результатом научного исследования по выявлению направлений повышения качества формирования профессиональных компетенций экономистов в современном украинском университете в условиях евроинтеграчии. По современному украинскому законодательству качество образования формируется внешней системой, которую поддерживает МОНУ и НАЗЯВО и внутренней системой, которую каждый учреждение высшего образования формирует самостоятельно. Евроинтеграчионное направление развития экономики Украины требует большей автономии университетов для более быстрого реагирования на запросы специалистов для рынка труда. Внешнее оценивание качества образования в виде ежегодных рейтингов высших учебных заведений влияет на выбор абитуриентов и часто их родителей при избрании заведения для обучения. Абитуриенты при выборе учреждения высшего образования для дальнейшего обучения часто пользуются информачией, полученной в сочиальных сетях. Формируя внутреннюю систему качества образования учреждения высшего образования, нужно позаботиться о правдивой информачии об университете в различных источниках информачии. Сформированная матрица SWOT-анализа системы формирования профессиональных компетенций бакалавров и магистров по экономике позволила выявить сильные стороны, недостатки, возможности и угрозы современной системы качества в украинском учреждениях высшего образования. Выделено подсистемы внешнего и внутреннего уровней системы обеспечения качества образования. Внутренняя система качества образования состоит из следующих подсистем: мониторинга соответствия профессиональной подготовки преподавателей требованиям МОНУ; мониторинга качества преподавания учебных дисииплин; мониторинга приобретенных компетенций студентов; мониторинга соответствия профессиональных компетентентностей, которые заложены в образовательно-профессиональных и образовательно-научных программах, реалиям рынка труда; стратегического планирования развития системы качества образования университета. Для подсистем внутреннего уровня системы обеспечения качества образования подобрано соответствующие современные инструменты, которые дают возможность осуществлять качественное измерение. Перспективными направлениями повышения уровня качества образования в украинских университетах есть практико ориентированное обучение студентов, связь с работодателями и согласования содержания образовательно-профессиональных программ со специалистами-практиками, осуществление научных исследований студентами во время обучения в университете.

Ключевые слова: Украина; система образования; качество; SWOT-анализ; компетентности; научные исследования; подготовка экономистов; евроинтеграция.

\title{
PROVIDING QUALITY OF FORMING PROFESSIONAL COMPETENCES OF ECONOMISTS IN THE MODERN UKRAINIAN UNIVERSITY IN CONDITIONS OF EUROINTEGRATION
}

\author{
Valeryia Loiko, \\ DSC (Economics), Professor of the Finance and Economics Department, \\ Borys Grinchenko Kyiv University \\ ORCID iD 0000-0003-3248-1585 \\ e-mail:v.loiko@kubg.edu.ua

\section{Daria Loiko,} \\ Candidate of Economic Sciences, Associate Professor, \\ Doctoral student of the Department of Theoretical and Applied Economics, \\ Chernihiv National University of Technology, \\ Chernihiv, Ukraine \\ ORCID iD 0000-0002-2443-2719 \\ e-mail: loyko_d@i.ua
}

\begin{abstract}
This article is the result of the scientific study on identifying areas for improving the quality of the formation of professional competencies of economists in the modern Ukrainian university in conditions of European integration. According to the existing Ukrainian legislation, the quality of education is formed by the external system supported by the Ministry of Education and Science of Ukraine (MESU) and the National Agency for Quality Assurance in Higher Education and the internal system that is formed by each institution of higher education independently. The European integration trend of Ukrainian economy requires greater autonomy of universities to respond more quickly
\end{abstract}


to the demand for specialists on the labor market. External assessment of the quality of education in the form of the annual ratings of institutions of higher education affects the choice of entrants and often their parents in choosing an institution for study. Very often the applicants for choosing a higher education establishment for further study rely on the information found on social networks. When forming the internal system of education quality assurance in an institution of higher education it is necessary to take care of the true information about the university in various sources of information. The matrix of the SWOT analysis of the system of formation of professional competencies of bachelors and masters in economics has revealed the strengths, weaknesses, opportunities and challenges of the current quality assurance system in Ukrainian higher education establishments. The internal quality assurance system of education consists of the following subsystems: monitoring compliance of lecturers' professional training with the requirements of the MESU; monitoring the quality of teaching disciplines; monitoring of acquired competencies by students; monitoring of conformity of professional competencies, which are laid down in educational-professional and educationalscientific programs, with the realities of the labor market; strategic planning of the development of the university's system of education quality assurance. For subsystems of the internal level of the education quality assurance system, appropriate modern tools have been selected that make it possible to introduce a qualitative dimension. Promising ways to improve the quality of education in Ukrainian universities are the practice-oriented student learning, the relationship with employers and the alignment of the content of educational and professional programs with practitioners as wel as more active engagement of students in doing research during their study at the university.

Key words: Ukraine; system of education; quality; SWOT-analysis; competences; scientific studies; training of economists; Eurointegration.

\section{REFERENCES (TRANSLATED AND TRANSLITERATED)}

1. Law of Ukraine. About Higher Education № 1556-VII. (2014, July 01). Retrieved November 12, 2018, from https://zakon.rada.gov.ua/laws/show/1556-18

2. Law of Ukraine. About education № 2145-VIII. (2017, September 05). Retrieved November 12, 2018, from http://search.ligazakon.ua/l_doc2.nsf/link1/T172145.html

3. Decree of the President of Ukraine № 344/2013. On the National Strategy for the Development of Education in Ukraine until 2021. (2013, June 25). Retrieved November 15, 2018, from https:// zakon3.rada.gov.ua/laws/show/344/2013

4. Aleksandrova, O., Batchenko, L., Dielini, M., \& Lavryk, U. (2018). Specifics of Managing Competitiveness of Present-day University on Principles of Social Responsibility. Naukovyi Visnyk Nacionalnogo Hirnychogo Universitetu,4, 157-165.

5. Quality management systems ISO 9001:2015. (2015). Retrieved November 10, 2018, from http:// khoda.gov.ua/image/catalog/files/ 9001.pdf 